\title{
Replacement value of African Bread Fruit Seed Meal (Treculia africana) for Maize on the Performance of Starter Broilers.
}

\section{Valor de reemplazo de la harina de semillas de pan africano (Treculia africana) para el maíz en el rendimiento de los pollos de engorde.}

\author{
AHAOTU, E.O ${ }^{1 *}$, ATURUCHI, W ${ }^{1}$, UNAGU, A $^{1}$ and UZEGBU, H.O ${ }^{2}$ \\ ${ }^{1}$ Department of Animal Production and Health Technology, Imo State Polytechnic Umuagwo, \\ Nigeria. \\ ${ }^{2}$ National Agricultural Extension Research and Liaison Service, Ahmadu Bello University Zaria, \\ Kaduna State, Nigeria.
}

\section{ABSTRACT}

An experiment was conducted to see the effect of parboiled and varying levels of boiled African breadfruit seeds (ABS) fed to starter broilers. The starter broilers were assigned to six treatment groups (control, parboiled, 10, 20, 30 and 40 minutes boiled ABS) with each of the treatments replicated three times in a completely randomized design (CRD). The diets were formulated to be iso-nitrogenous (22\% CP) and iso-caloric (2700 Kcal/kg ME). Water and feed were offered ad libitum. Results shows that all parameters at the performance of starter broilers fed varying levels of boiled ABS were significantly $(P<0.05)$ different with most of the significant level favouring the treatment T4 which is boiling at 20 minutes. Inclusion of boiled ABS into the diet of starter broilers improved the performance of the birds. It could therefore be concluded that ABS can serve as alternative nutritive source of nutrition in the diet of starter broilers.

Keywords: African breadfruit seeds, Maize, Performance, Starter Broilers, Replacement value.

\section{RESUMEN}

Se llevó a cabo un experimento para ver el efecto de los niveles precocidos y variables de semillas de fruta de pan africana hervida (ABS) alimentadas a los pollos de engorde. Los pollos de engorde iniciales se asignaron a seis grupos de tratamiento (control, precocido, 10, 20, 30 y 40 minutos de ABS hervido) con cada uno de los tratamientos replicados tres veces en un diseño completamente aleatorizado (CRD). Las dietas fueron formuladas para ser isonitrogenadas (22\% CP) e isocalóricas (2700 Kcal / kg ME). El agua y el alimento se ofrecieron 
ad libitum. Los resultados muestran que todos los parámetros en el rendimiento de los pollos de engorde iniciadores alimentados con niveles variables de ABS hervido fueron significativamente $(P<0.05)$ diferentes, con la mayor parte del nivel significativo favoreciendo el tratamiento T4 que está hirviendo a los 20 minutos. La inclusión del ABS hervido en la dieta de los pollos de engorde iniciales mejoró el rendimiento de las aves. Por lo tanto, se podría concluir que el ABS puede servir como fuente nutritiva alternativa de nutrición en la dieta de los pollos de engorde.

Palabras clave: semillas de pan de África, maíz, rendimiento, pollo de engorde de arranque, valor de reemplazo.

\section{INTRODUCTION}

Livestock production represents a major investment with important economic, nutritional and social implications for developing countries. The levels of animal protein consumption, however, in these countries have been reported to be very low and, generally, influencing the health and well-being of the ever increasing population (Ahaotu et al., 2018a).

The high cost of feed in most tropical countries clearly indicates that the production of cereal grains for livestock business is grossly inadequate (Ahaotu et al. 2017). Furthermore, the stiff competition existing between humans and animals over the available grains has resulted in the near collapse of the poultry industry in Nigeria (Ayo-Enwerem et al., 2017). There is urgent need therefore to turn attention to exploitation of other tropical sources. African Breadfruit (Treculia Africana) seeds are exemplary of this unrealized potential.

African breadfruit (Treculia Africana) seeds and shells have been neglected and under exploited. It is a tropical tree belonging to the taxonomic family Moracceae and found mostly along the guinea savannah to the forest zone of Nigeria. For identification, Ugwu and Oranye, (2006) described the plant to produce large, round, compound fruits covered with pointed outgrowths, with seeds buried in the spongy pulp. It is also known for its large fruit heads which is rich in energy, protein, minerals and vitamins (Oyetayo and Omenwa, 2006).

The pulp is nutritious if adequately processed to reduce the levels of some anti-nutrients contained in the seeds which may interfere with the process of digestion and performance when fed to birds and animals (Ijeh et al., 2010). When the seeds are in its raw form, it can be processed by boiling, toasting, fermentation before it can be incorporated into diet for poultry and rabbits to replace part of the carbohydrate or protein source in their diet (Obiakor-Okeke and Nnadi 2014). Also, report shows that the potential industrial uses of the bread fruit have not been sufficiently explored and investigated, even where it is used, determining what processing method and performance on livestock has not been evaluated other than attempts aimed at determining its chemical composition (Oso et al., 2010). 
Currently, efforts in livestock feeding are focused on increasing livestock feed base by adapting animal production system to locally available feed resources. Among the ecologically available forest based feed resources with good biomass production which can be converted into feed (for livestock) is the African breadfruit (Treculia Africana) which is found in the wild (Oso et al., 2010). It is a sub-tropical fruit-bearing tree which stores mainly carbohydrates in its fruits. African breadfruit produces fruit 2-3 times in a year and the number of fruits produced is very high (Nwabueze and Uchendu, 2011). The fruit is aromatic, rich in latex and weighing up to 1-4 $\mathrm{kg}$ (Oso et al., 2010).

Oyetayo and Omenwa (2006) reported that the potential industrial uses of the African bread fruit have not been sufficiently explored and investigated other than attempts aimed at determining its chemical composition. African breadfruit offers high potential in livestock nutrition containing $86.27 \%$ dry matter, $12.98 \%$ crude protein, $4.22 \%$ crude fibre, $3.94 \%$ ash and a metabolisable energy of $3870.30 \mathrm{kcal} / \mathrm{kg}$ (for poultry) (Nwabueze et al., 2008a). African breadfruit as alternative energy feedstuffs in rabbit nutrition has not been extensively explored although Nwabueze et al., (2008b) reported that African breadfruit could be processed into meal suitable for poultry.

There is increased awareness of the importance of legumes in the diet of Nigerian populace. The main contribution of legumes to the diet of Nigerians is based on their nutritional values. African bread fruit (Treculia africana) is one of mankind's important sources of nutrients such as vitamins, carbohydrates, minerals, proteins and fat. African bread fruit is a very important indigenous fruit which generally play a vital role in the diet of man (Obiakor-Okeke and Nnadi, 2014). African breadfruit (Treculia africana) is a monoecious evergreen fruit belonging to the family of Moracceae. Seed production of African bread fruit is considerable; a mature tree produces up to 30 fruits annually, each fruit yielding 5 - $10 \mathrm{~kg}$ of seed after processing. The fruit contains black or brown seeds that can be peeled twice and cooked like chestnut. The seeds of bread fruit are rich in protein, fat, carbohydrate, and vitamins and eaten in many part of African (Kabuo, 2001). African breadfruit is a grain legume which is currently being considered as several sources of nutrient. It contributes immensely to the diet of Nigerians.

The seed resemble the groundnut when roasted in flavour and uses and it may be processed into flour apart from being cooked and eaten as a main dish (Adebowale et al., 2008; Abiodun et al., 2014). The raw seed as well as the edible cotyledon are obtained after parboiling and dehulling. African breadfruit 'Ukwa' in Igbo Language is mostly consumed in Igbo land and other parts of the southern states of Nigerian. During festive seasons, the rural homes use it as complementary foods to replace expensive foods. In Igbo land and elsewhere, "Ukwa" is a free legume that produces fruits. The fruits are hung on the stem and branches and take about four months-to mature. 
Breadfruit seeds are used to prepare various traditional dishes. They could be roasted, consumed with soups, pound boiled or mashed to make pottage. Breadfruit is much more cherished and utilized in Igbo speaking part of Nigerian and other south east state. In other parts of Nigerian, the crop is not widely cherished due to ignorance of its nutritional potentials, processing preparation and utilization (Adedeji et al., 2015). A major constraint in the utilization of African breadfruit is the difficult dehulling involved in the manual removal of the hulls from the parboiled seeds. This method is quite laborious, time consuming and does not favour effective utilization of the fruit. Another constraint is the long cooking time. Such long cooking time and high temperature can result to loss of flavour and nutrients (Adedeji et al., 2015). Roasting and cooking are high temperature heat treatments of foods.

All the major food processing treatment in current use, heat processing is the most encountered and it has a very important effect on various food components and quality (Akubor et al., 2000). Depending on such factors as time, temperature, moisture content, presence or absence of reducing or oxidizing agents and. other ingredients such as acid, salt, sugars, fat, and other chemicals, heat treatment may have either beneficial or detrimental effects. Thus heat treatment on food must be carefully controlled to avoid or minimized damage to nutritive value, functionality, and sensory properties which determine acceptability. The aim of this study is to determine the extent of effect processing has on the proximate and mineral content of African breadfruit. The result of the study would be of value to consumers because it will create general awareness of the nutritional potentials of African breadfruit (Treculia africana) and the effects of the different processing methods by carefully controlling heat treatment to avoid or minimize damage to nutritive value, which determine acceptability (Agbon, et al., 2010; Obiakor-Okeke and Nnadi, 2014)

The objectives of the study were to determine the effect of various boiling duration of $A B S$ on the performance of starter broilers and to evaluate the nutritional value of bread fruit meal for maize in diets of starter broilers.

\section{MATERIALS AND METHODS}

Location of Study Area: the study will be conducted at the Poultry Unit of Imo State Polytechnic Umuagwo. Imo State Polytechnic Umuagwo is located at the site is situated between longitudes $7^{\circ} 0^{1} 06^{11} \mathrm{E}$ and $7^{\circ} 03^{1} 00^{11}$ and latitudes $5^{\circ} 28^{1} 00^{11} \mathrm{~N}$ and $5^{\circ} 30^{1} 00^{11} \mathrm{~N}$ in the humid tropical West Africa (IMLS, 2009). The climate is marked by two seasons.

Sampling and Sample Preparation. African breadfruit (Treculia Africana) seeds will be collected during the rainy season from the parent plant located at Inyishi, Ikeduru Local Government Area of Imo State, Nigeria in April, 2017. The samples were identified at the Department of Crop Science Technology, Imo State Polytechnic Umuagwo. Stones and other 
large particles were removed from the raw sample and then washed with distilled water to remove extraneous matter.

Method of processing of African breadfruit seed: raw African breadfruit seeds will be parboiled at $100^{\circ} \mathrm{C}$ for 15 minutes to facilitate dehulling. The dehulled seeds will be sun dried for about 48 hours (Fasasi et al., 2003). Batches of $20 \mathrm{~kg}$ African breadfruit seeds sun dried will be subjected to various durations of cooking time which includes: 10, 20, 30 and 40 minutes and each duration of boiling represents a treatment (Ijeh, et al., 2010). For each boiling time, 40 liters of water was brought to boiling point in a 200- litre drum container (Adedeji et al., 2015). A batch of $25 \mathrm{~kg}$ African breadfruit seed was then immersed into the boiling water. From this point, the specified time for boiling was taken. At the end of this period of boiling, excess water was drained off and the boiled seeds were sun-dried.

Formulation: six experimental diets were formulated for the study. The African breadfruit seeds (ABS) were included at $5 \%$ level in the diets. Treatment 1 : were $0 \%$ inclusions of $A B S$, Treatment 2: was Parboiled ABS, Treatment 3: was ABS cooked for 10 minutes, Treatment 4: was ABS cooked for 20 minutes, Treatment 5: was ABS cooked for 30 minutes and Treatment 6 : was ABS cooked for 40 minutes respectively.

Experimental Design and management of experimental birds: one hundred and twenty (120) starter broilers were used for this study. The birds were assigned to six treatment groups with their average initial body weight taken. Each treatment group of 20 birds was further subdivided into four replicates of 5 birds per pen in a completely randomized design (CRD). Experimental diets and water were provided ad libitum. The diets were fed to the starter broilers for a period of four weeks after a standardization period of one week. Body weight of birds in each replicate group was taken at the beginning and then weekly till the end of the study. The percent change in body weight was calculated by subtracting the initial weight of birds from the final weight. Feed intake, weight of feed/bird/day were determined by obtaining the differences between the quantity of feed offered and the left over on 24 hour period. Feed conversion ratio was calculated weekly. Mortality record was also be recorded.

Data Analysis: results were expressed as mean values and standard deviation of five (5) determinations. The obtained data will be analysed using a one-way analysis of variance (AOAC, 2000) (ANOVA). Duncan New Multiple Range Test was used to separate the means where significant differences existed. 
Table 1: Composition of diets based on raw African breadfruit seeds and African Bread fruit seeds boiled at $100^{\circ} \mathrm{C}$ for varying length of time for Starter Broilers (1-4 weeks).

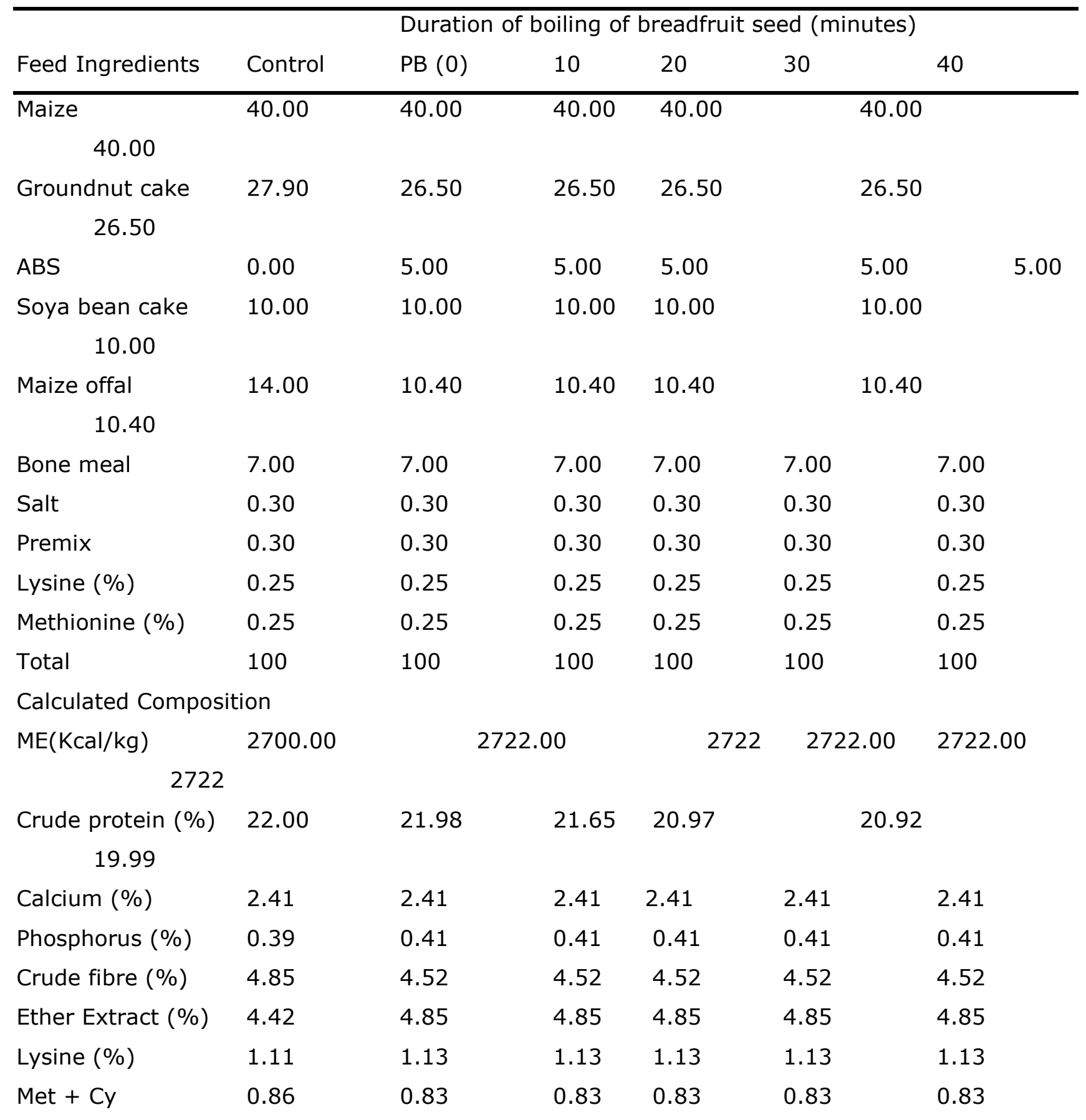

*Bio-mix premix supplied per kg diet-vitamin A, 10,000.00 i.u; vitamin $D_{3} 2,000.00$ i.u; Vitamin E 23,000.00mg; Niacin 27.5mg; Vitamin $B_{1} 1.800 \mathrm{mg}$; Vitamin $B_{6} 30 \mathrm{mg}$; Vitamin $B_{12} 0.015 \mathrm{mg}$, Vitamin K3 200mg; Pantothenic Acid 7,500; Biotin $\mathrm{H}_{2}$ 0.06; Folic Acid 0.75mg; Chlorine Chloride $300.00 \mathrm{mg}$; Cobalt 0.2mg; Copper 30mg; Iodine $1.00 \mathrm{mg}$; Iron 200.00mg; Manganese 0.04mg; Selenium 0.2mg; Zinc 30mg; Antioxidant $1.25 \mathrm{mg}, \mathrm{PB}=$ Parboiled. 
Table 2 a: Toxicant composition of seeds of African bread fruit (Treculia africana)

\begin{tabular}{lc}
\hline Toxicants & Composition $(\mathrm{mg} / 100 \mathrm{~g} \mathrm{DM})$ \\
\hline Hydrocyanide & $0.06 \pm 0.12$ \\
Oxalate & $3.01 \pm 0.11$ \\
Phytic acid & $0.76 \pm 0.01$ \\
\hline
\end{tabular}

Table 2b: Proximate composition and energy levels of experimental diets based on parboiled African breadfruit seeds (ABS) and $A B S$ boiled at $100^{\circ} \mathrm{C}$ for varying length of time for Starter Broilers (1-4 weeks).

\begin{tabular}{llllllll}
\hline \multicolumn{7}{c}{ Boiling durations of ABS (minutes) } \\
& $\mathrm{T}_{1}$ & $\mathrm{~T}_{2}$ & $\mathrm{~T}_{3}$ & $\mathrm{~T}_{4}$ & $\mathrm{~T}_{5}$ & $\mathrm{~T}_{6}$ \\
\hline Parameters (\%) & Control & $\mathrm{PB}(0)$ & 10 & & 20 & & 30 \\
\hline Dry Matter & 93.36 & 93.48 & 94.44 & 92.82 & 92.77 & 93.48 \\
Crude Protein & 21.52 & 21.56 & 20.98 & 20.88 & 21.43 & 22.01 \\
Crude Fibre & 5.86 & 6.04 & 6.23 & 5.49 & 5.38 & 5.77 \\
Ether Extract & 4.76 & 4.89 & 5.20 & 5.58 & 4.78 & 5.99 \\
Ash & 7.67 & 7.39 & 8.04 & 8.21 & 7.67 & 7.98 \\
NFE & 60.19 & 60.12 & 59.55 & 59.84 & 60.74 & 58.25 \\
Energy (MJ/Kg) & 13.42 & 18.40 & 15.66 & 19.66 & 18.60 & 16.33 \\
\hline
\end{tabular}

$\mathrm{NFE}=$ Nitrogen Free Extract, $\mathrm{PB}=$ Parboiled

Table 2c: Proximate and mineral composition of Bread Fruit Seed Meal

Proximate

Moisture

Crude protein

Crude lipid

Crude fibre

Ash

Minerals

$P$

$\mathrm{Na}$

\section{$(g / 100 g)$}

\section{3}

6.1

\section{4}

36

5.2

$(\mathrm{mg} / \mathrm{kg})$

0.53

40.79 
$\mathrm{P}=$ Phosphorus; $\mathrm{Na}=$ Sodium; $\mathrm{K}=$ Potassium; $\mathrm{Ca}=$ Calcium; $\mathrm{Mg}=$ Magnesium; $\mathrm{Fe}=\mathrm{Iron} ; \mathrm{Cl}$ $=$ Chloride, $\mathrm{Mn}=$ Manganese, $\mathrm{Cu}=$ Copper, $\mathrm{Zn}=$ Zinc.

Table 2 d: Phytochemical screening of the seeds of African Bread Fruit (Treculia africana)

\begin{tabular}{lcc}
\hline Phytochemicals & Alcoholic extract & Water extract \\
\hline Alkaloids & - & - \\
Flavonoids & ++ & + \\
Polyphenols & ++ & + \\
Anthraquinone & ++ & + \\
Saponins & ++ & + \\
Phlobotanins & - & - \\
Tannins & - & - \\
Cardiac glycosides & ++ & + \\
Anthhrraroids & - & - \\
\hline
\end{tabular}

\section{RESULTS AND DISCUSSION}

Table 3 shows the effect of duration of boiling of African breadfruit seeds on the performance of starter broilers during the experimental period. The result showed significant $(P<0.05)$ difference in all parameters measured for starter broiler performance. The diet cooked for 20 minutes had the best performance and was similar to parboiled diet and diet cooked for 30 minutes in most parameters compared. However, finial body weight was higher in the treatment boiled for 20 minutes, which was similar to those cooked for 10 minutes, while the raw and parboiled treatments yielded the lowest body weights while daily feed intake and total feed intake increased as the boiling durations increased. 
Starter Broilers fed the raw ABS diet had significantly reduced growth rate (evidenced by body weight changes) compared to those fed the boiled (10, 20, 30 and 40 minutes) ABS diets. This observation is consistent with the report of Ugwu and Oranye (2006). These authors reported that raw and improperly heated legume seeds fed as the main source of protein in diets for monogastrics can depress growth and efficiency of feed utilization. However, the general improvement in weight gain as the duration of boiling of ABS increased in the present study also agreed with the reports of (Ahaotu et al., 2018b and Ajayi, 2008). There were improvements in feed intake, weight gain, and feed conversion ratio in the quails fed cooked ABS when compared to the raw $A B S$ in the laying phase and this may have led to the improvement of the efficiency of protein utilization. This observation is in consonance with the reports of (Ahaotu et al., 2018a) that the nutritive value of jack bean seeds was improved when subjected to cooking. These were attributed to better protein absorption, detoxification of anti-nutritional factors, higher palatability and availability of amino acids in the diets.

Table 3: The effect of duration of boiling of African breadfruit seeds (ABS) on the performance of Starter broiler (0-4 weeks).

Duration of boiling of African breadfruit seeds (minutes)

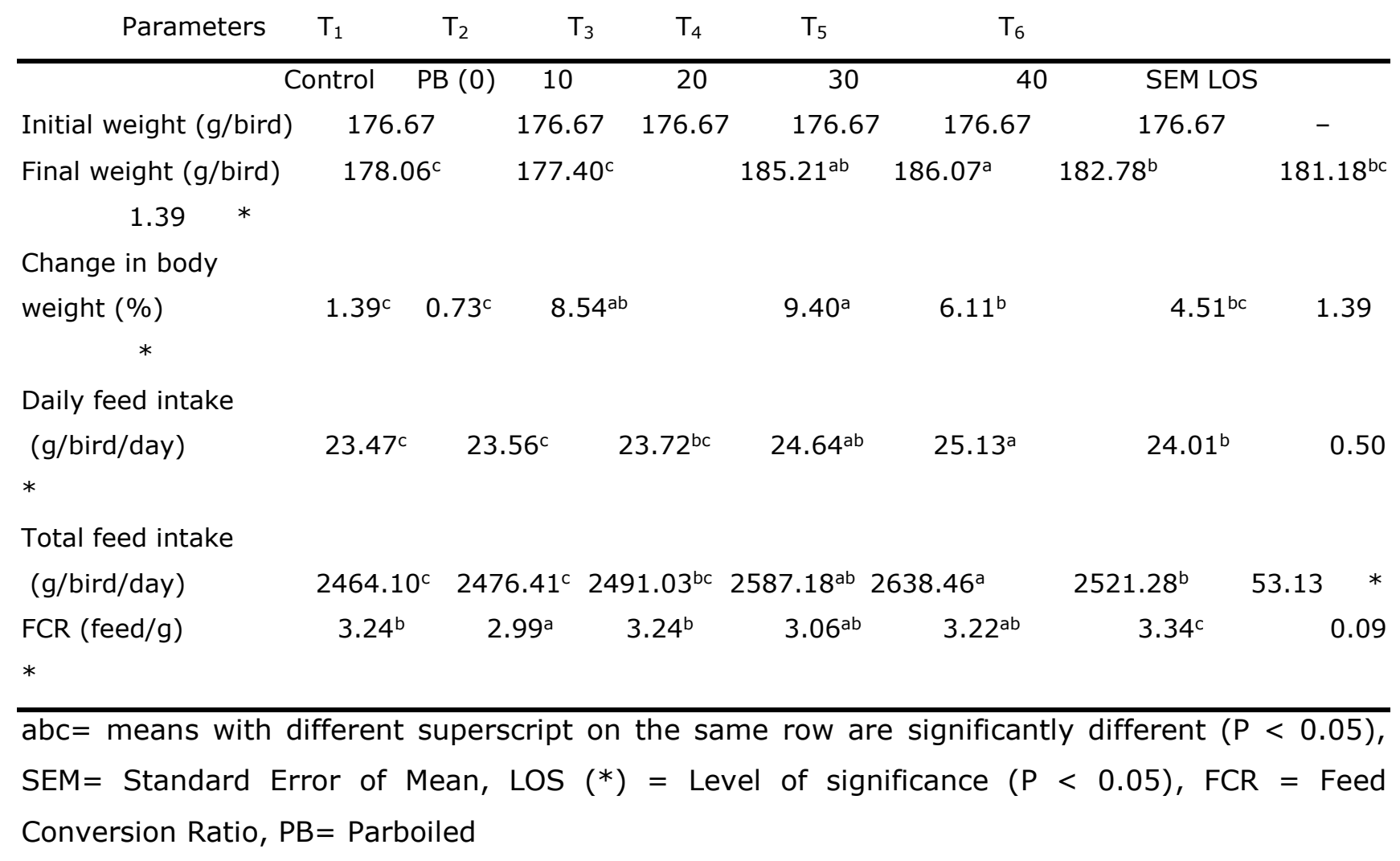

As conclusion, African breadfruit offers high potential as feed ingredient in poultry nutrition due to its high protein and energy value and could therefore be used as alternative energy feedstuffs in place of maize in broiler feeds. The findings of this work indicated that 
boiled African breadfruit seed (BABFS) could be used successfully to replace $40 \%$ maize in a starter broiler diet with optimum growth response. Beyond this inclusion, carcass yield are compromised.

The African bread fruit seed contain high level of carbohydrate and protein but is relatively low in fat, ash and fibre. The low content of hydro cyanide, oxalate and phytase in the seed makes it both non-toxic and non-poisonous when used as food or feed. In addition the seeds were high in $\mathrm{K}, \mathrm{Mg}$ and $\mathrm{Ca}$ but may need to be fortified with $\mathrm{Na}$, Fe and $\mathrm{Zn}$ when used in food formulation because of their low inherent levels.

Furthermore the inclusion of boiled African breadfruit seed in the diets of starter broilers did influenced their performance. Boiled African breadfruit seed diets did not show any negative effect on the tested animals.

\section{REFERENCES}

Abiodun A.Olapade and Umeonuora,U.C (2014). Chemical and Sensory Evaluation of African Breadfruit (Treculia africana) seeds proceesed with Alum and Trona. Nigerian Food 80 88. Doi 10.1016/s0189-7241 (15) 30099-0

Adedeji E. Olajide; Damilare E. Jegede; Khadijat O. Abdulsalam; Uchenna E. Umeohia; Oluwafemi A. Ajayi and Joseph E. Iboyi (2015). Effect of Processing Treatments on the Proximate, Functional and Sensory Properties of Soy-Sorghum-Roselle Complementary Food. British Journal of Applied Science \& Technology 6(6): 635-643

Adebowale A. A., Sanni S. A. and Oladapo F. O. (2008). Chemical, functional and sensory properties of instant yam breadfruit flour. Nigerian Food Journal 26: 2-12.

Adekunle. K.S.A., Fanimo, A.O., Abiola, S.S and Akegbejo-Samson, Y. (2006). Potential of Bread fruit meal as Alternative energy source to maize in diet of broiler chicken. Journal of Poultry Science 41: 241-249

Agbon, C.A, C.O. Akinyemi, A. Adeleke, and E.C. Okeke (2010). Chemical and sensory characteristics of fufu made from mixtures of cassava and African breadfruit flours. Journal of Natural Sciences, Engineering and Technology, 9. 84-89

Ahaotu, E.O, Emeribe, E.O and Akinfemi, A. (2018a). Carcass and Performance Characteristics of Finisher Broiler Birds Fed Jack Bean (Canavalia ensiformis) Sievate Fortified with Exogenous Enzyme. Journal of Meat Science and Technology, 6: 19-24.

Ahaotu, E. O, Amajioyi, N and Okorie, K. C (2018b). Sustainability of Guinea Fowl (Numidia Meleagris) Layers Fed varying Levels of Centrosema Pubescent Leaf Meal. Direct Res. Journal of Veterinary Medicine and Animal Sciences 3: 28-35.

Ahaotu, E.O, B.U. Ekenyem and E. Aggrey (2017). Sustainability of sweet orange (Citrus sinensis) peel meal on the performance of finisher Broilers. Journal of Agricultural Science and Practice. Journal of Agriculture Sciences and Practices, 2: 27-32. 
Ajayi I.A. (2008). Comparative study of the chemical composition and mineral element content of Artocarpus heterophyllus and Treculia africana seeds and seed oils. Bio resource Technology, 99: 5125- 5129.

Akubor PI, Isolokwu PC, Ugbane O and Onimawo IA. (2000). Proximate composition and functional properties of African breadfruit kernel and flour blends. Food Research International, 33: 707-712.

AOAC (2001). Official Methods of Analysis. Association of Official analytical Chemists Washington D. C., pp 235-237.

Ayo-Enwerem, M.C, Ahaotu, E.O, Nwogu, C. M. and Opara, J. (2017). Growth performance of starter broilers fed diets containing red sandalwood (Pterocarpus santolinoides) leaf meal. Direct Research Journal of Veterinary Medicine and Animal Science, 2: 106-109.

Ejidike B.N and Ajileye .O (2007) Nutrient composition of African breadfruit (Treculia africana) seed hull and its use in diets for the African Giant Land Snail, Archachatina marginata. Pakistan Journal of Nutrition, 6: 201-203

Fasasi O.S, Eleyinmi A.F, Fasasi A.R and Karim O.R (2003). Chemical properties of raw and processed breadfruit (Treculia africana) seed flour. African Crop Science Conference Proceedings, 6. 547-551.

Ijeh, I.I., C.E. Ejike, O.M. Nkwonta, and Njoku, B.C. (2010). Effect of traditional processing techniques on the nutritional and phytochemical composition of African breadfruit (Treculia africana) seeds. Journal of Applies Sciences and Environment Management, 14: $169-173$.

Kabuo, C.O.O. (2001). Extending shelf-life of African breadfruit (Treculia africana) seeds "Ukwa" (180) by solar drying: effect on proximate composition and Organoleptic quality. In proceedings of 25th Annual NIFST conference, 5-9, Lagos.

IMLS (2010). Imo State Ministry of lands and survey - Detailed Atlas of the State.

Nwabueze T.U. and Uchendu C.B. (2011) African Breadfruit (Treculia africana) Seed as Adjunct in Ethanol Production. European Journal of Food Research \& Review 1(1): 15-22

Nwabueze M. O., Titus U., Akobundu N. T. and Iwe E. (2008a). Physical characteristics and acceptability of extruded African Breadfruit-Based snacks. Journal of Food Quality 31:142-155.

Nwabueze, T.U., Atuonwu, A.C., and Lawal, R.O. (2008b). Effect Of Malting African Breadfruit (Treculia Africana) Seeds On Flour Properties And Biscuit Sensory And Quality Characteristics As Composite. Journal of Food Technology, 126.

Nwokocha L.M and Ugbomoiko J.O (2008). Effect of parboiling on the composition and physicochemical properties of Treculia africana seed flours. Pakistan Journal of Nutrition, 7: 317-320. 
Obiakor-Okeke P.N. and Nnadi C. C, (2014).The Effect of Different ProcessingMethods on the Nutrient and Anti- Nutrient Composition of African breadfruit (treculia Africana). International Journal of Nutrition and Food Sciences, 3. 333-339.

Oso, A.O., R. Faboro, O. Isah, A. Oni, A. Bamgbose, and Dele, P. (2010). Potential of breadfruit (Artocarpus altilis) an ecological forest based feed resource in rabbit nutrition. Tropical and Subtropical Agroecosystems, 12: 99 - 108.

Oyetayo, V.O., and Omenwa, V.C. (2006). Microbial and Chemical Qualities of Raw and Trona Processed African Breadfruit (Treculia africana Decne). American Journal of Food Technology, 1: 77-80.

Ugwu, F.M., and Oranye, N.A, (2006). Effects of some processing methods on the Toxic Components of African breadfruit (Treculia Africana). African Journal of Biotechnology. 5 : 2329-2333 